PATrick Gill

Johannes Gutenberg University Mainz

\title{
Dystopian and Utopian Omission of Discourse in Three Modern Robinsonades: Lord of the Flies, Concrete Island, The Red Turtle
}

The reader of Daniel Defoe's Robinson Crusoe encounters a narrative self-consciously shaped by an intradiegetic narrator with the aim of unburdening his mind and creating a sense of order in and control over his own story: "I drew up the State of my Affairs in Writing, not so much to leave them to any that were to come after me $[\ldots]$ as to deliver my Thoughts from daily poring upon them, and afflicting my Mind" (49). This simple recipe is somewhat complicated by the addition of the voice of an older Robinson figure looking back on his adventures to the journal kept by Robinson in extremis. Where the younger Robinson on the island can occasionally fail to grasp the meaning of events around him, the older Robinson can step in and - with the benefit of hindsight - discern the workings of Providence in his younger self's life. Thus the story provides a sense of immediacy and jeopardy on the one hand while also offering retrospective wisdom and control on the other. What becomes increasingly clear through the telling of the story, however, is the fact that its main purpose is the shaping of reality into something that makes sense to the protagonist narrator as well as his readers. As Richetti elaborates:

Defoe's "realism" as a novelist comes in his vivid evocation of individuals as they examine the conditions of their existence and explore what it means to be a person in particularized social and historical 
circumstances. Looking back on their lives, his characters discover the nature of their particular reality. They reveal how they adapted to their circumstances, how they modified actuality as they encountered it and constructed personal versions of "reality". (121)

This process of Robinson's constructing his personal reality through storytelling is frequently overshadowed in readers' minds by Robinson's efforts in changing his physical environment. I would however argue that the fashioning of the story to fit the perceived providential plan underlying his experiences is no less important than Robinson's activities in making the island habitable. So dominant is this aspect of Robinson Crusoe that it has spawned an entire tradition of adaptations and other Robinson-related texts availing themselves of intradiegetic narrators more or less consciously constructing stories that attempt to shape the realities they find themselves in. Thus, besides shipwrecks and desert islands, what has characterised the form of the Robinsonade is its tendency to provide "a self-reflexive, critical meta-commentary" (Kinane 217). Writers have been exploiting the form's propensity for meta-reflection for centuries. From R.M. Ballantyne's The Coral Island (1858) and H.G. Wells's The Island of Doctor Moreau (1896) via Joanna Russ's We Who Are about To (1977), J.M. Coetzee's Foe (1986), Marianne Wiggins's John Dollar (1989), and Umberto Eco's The Island of the Day Before (1994) to Yann Martel's Life of Pi (2001) and Andy Weir's The Martian (2011), prominent writers across the centuries have made use of the meta-narrative potential provided by Defoe's original novel. Instead of further expanding on this list by way of an even more extensive list or detailed discussion of any one specimen novel, I suggest to demonstrate the centrality of the narrator figure for the Robinsonade by taking a brief look at two twentieth-century plays. Surely here, the foregrounding of a narrative situation would have to be forgone for some more dramatic means of conveying a story: on stage, mimesis would have to take over from diegesis.

\section{Stage Robinsons between Mimesis and Diegesis}

J.M. Barrie's 1902 play The Admirable Crichton turns the Robinson story into a comedy of manners. In doing so, it does not relinquish the idea of a prominent narrative voice, though, retaining the storyteller's role in the form of its excessive stage directions. Rather than offering practical instructions, the stage directions here are characterised by a discursiveness and tendentiousness more akin to gossip than dramaturgy. The personal pronoun "we" is used to refer to both the 
author surrogate and a stand-in for the audience. Consider the introduction of the titular character:

It would not be good taste to describe Crichton, who is only a servant; if [...] he is to stand out as a figure in the play, he must do it on his own, as they say in the pantry and the boudoir. We are not going to help him. We have had misgivings ever since we found his name in the title, and we shall keep him out of his rights as long as we can. Even though we softened to him he would not be a hero in these clothes of servitude; and he loves his clothes. How to get him out of them? It would require a cataclysm. (3-4)

It is clear that the tone is employed in order to temper the reader's reaction when they are finally presented with the morally dubious proposition of the play's main plot. The fact that much of the story has been conveyed through the tonal equivalent of an arched eyebrow means constellations critical of the social status quo become more palatable. This, the stage directions seem to say, is a comedy of manners, not a revolutionary manifesto. So while one potential reality is presented on stage, the tone of the paratextual comments makes it clear that that is not the only or even the most plausible way of understanding the situation: the unnamed first-person-plural voice of the stage directions helps to shape a "modified actuality" (Richetti 121).

Written in radically different circumstances and for a radically different audience, Adrian Mitchell's Man Friday of $1974^{1}$ performs a reversal in which every interaction between Robinson and Friday is re-evaluated to uncover that in all their dealings, Robinson has been a selfish tyrant and Friday a patient companion. Their complex relationship is thus initiated here not by Robinson rescuing Friday from his captors but by Robinson interrupting a ritual and simply shooting Friday's friends Ivory and Weaver (9). What is needed to perform this radical revisionary act, however, is not just a scenic re-enactment of the plot but a narrative voice capable of reinterpreting the plot: a voice to refashion the story into an attack on white colonialism, selfishness, greed, and arrogance.

1 The play has a fairly labyrinthine publication history, having first been broadcast in BBC 1's Play for Today series in 1972 . Subsequently rearranged into a stage play, it was performed by the 7:48 Theatre Company on a tour of England in 1973. The year 1975 saw the first screening of the film Man Friday, starring Richard Roundtree and Peter O'Toole. The year given in the text is that of the appearance of the stage play in print. 
This voice is given to Friday himself, as the entire play stages moments retrospectively narrated by Friday to his fellow tribespeople. In providing the narrator with an onstage audience, the play not only offers an opportunity to radically re-think the story of Robinson and Friday, it also sets the communally-minded Friday and his tribe against the egocentric Robinson, a man who keeps insisting that there are "things which are for one person only and for nobody else" (14), a concept that seems deeply puzzling to Friday.

So central has the narrative situation become to notions of the Robinsonade that even dramatic texts show a tendency to persevere with narrative where their natural inclination should be to show rather than to tell. The aim of the present essay will be to analyse what happens when Robinsonades deliberately forgo the use of this potential to foreground the fact that they are narrative constructs, instead opting for a less self-reflexive presentation of their story. Given its universal fame, the first example to be discussed here provides an obvious starting point.

\section{Lord of the Flies and Failures to Re-establish Civilisation}

William Golding's Lord of the Flies (1954) has been grouped among the "anti-Robinsons," i.e. a category of "satiric, anti-adventurous" adaptations "designed to arouse moral anxiety and inhibit triumphal action" (Green 3). While the “anti-Robinson" label clearly refers to these Robinsonades' more pessimistic outlook in general, Golding's novel mirrors that pessimism when it comes to the question of who has control over the narrative. Presented as a third-person narration, the novel stakes no claim for any one character consciously shaping the narrative, reflecting the loss of overall control at the heart of the novel. If the boys stranded on the island in times of nuclear war fail to establish a cohesive social structure imitating the civilisation they find themselves isolated from, it goes to reason that the book cannot present a successful attempt at establishing a coherent master narrative by one of its characters. But the absence of a unified version of events is not simply an absence - it is in fact heavily signposted in Golding's novel. This signposting usually takes one of two forms: either by emphasising the efficacy of destructive discourse or by describing attempts at establishing an orderly discourse. The former is the case when the narrator switches from referring to one of the boys as "the fat boy" to calling him "Piggy" after Ralph was expressly asked not to use that nickname (11); it is also the case when rumours are spread about the possible presence of a "snake-thing" or "beastie" (35) presenting a danger to the children. The latter is the case every time the famous conch is made use of to establish who gets to speak (15). Pos- 
session of the conch should result in the right to speak, thus ensuring fair and civilised discourse, as well as equal opportunity to speak. But the entire system is soon undermined by the making up of other rules, as this exchange shows: "'I got the conch,' said Piggy indignantly. 'You let me speak!' 'The conch doesn't count on top of the mountain,' said Jack, 'so you shut up"' (41). Similarly, the maintenance of the signal fire could be seen as a form of communication integral to the boys' hopes of ever being rescued, but that, too, proves a challenge they will fail to master (188).

In fact, the absence of a narrative, of successful communication, is everywhere in the book, from the last remnant of civilisation the boys witness before the crash in the person of "the man with the megaphone," trying to communicate rules and guidelines in their hour of need (7) to the prophetic chasm opening up between Jack and Ralph to foreshadow the loss of friendship, empathy and mercy: "They walked along, two continents of experience and feeling, unable to communicate" (53).

What these highly effective ways of communicating evil and chaos on the one hand and the difficulty of establishing rational discourse in the face of a breakdown of all communication on the other signify in the novel, is the rapid decline of civilisational norms. Once these have been eroded by the quick establishment of negative messages (about Piggy's name, about the beastie) as well as a failure to establish new benevolent narratives in their stead, civilisation is defeated and only untamed barbarism remains: "We gather that only civilization, corrupt though it is, saves human beings from always living like that" (Green 181). The corruption of civilisation mentioned here is to be gleaned from the fact that the surviving boys are rescued from a situation in which they are hunting one another with deadly consequences by a navy ship on the lookout for enemy ships to destroy: the supposed safety of civilisation is thus shown to be nothing more than a veneer, the barbarism of the children only a different and unexpected expression of the same brutality manifest in the war the adults wage all around them. The breaking down of civilisation and of a cohesive narrative along with it is thus an expression of the fact that evil lurks within all of us and that civilisation can only temporarily stem the tide of animalistic brutality waiting to erupt from supposedly civilised human beings.

\section{Concrete Island and the Defeat of Humanity at Its Own Hands}

Where Lord of the Flies locates the corrupting power of barbaric evil in ourselves and posits that civilisation is a bulwark temporarily keeping humanity safe, J.G. Ballard's Concrete Island (1974) argues that civilisation itself is the 
thing that robs us of our humanity. The novel tells the story of Robert Maitland, a London architect, who one day finds himself stranded on the eponymous concrete island in the middle of the city. Seemingly incapable of climbing back up the embankment, attracting the attention of passers-by or otherwise communicating with the outside world, he soon has little hope of rescue. Where Robinson Crusoe manages to salvage tools and a gun from the shipwreck, the civilisatory remnants Maitland gets from his car consist of some wine (26) and the "water reservoir of the windshield washers" (34). Contracting a fever, Maitland soon finds himself in the care of two homeless people living on the traffic island, Jane and Proctor, whom he refers to as "mentally disturbed" (118) and a "tramp" (108) respectively. In a physical altercation with Proctor, the latter is described as "crouching like a nervous animal, unsure whether to assert his dominion over the island" (111). In fact, what happens is that Maitland, upon recuperation, proceeds to assert his dominion over Proctor in the least civilised terms imaginable, subjecting him to ritual humiliation (135).

To some extent, then, Concrete Island can be read as representing Maitland's story, Maitland's conquest of the island. In that reading, though, the question arises as to why the story is not narrated by him. After all, like Lord of the Flies before, Concrete Island is a third-person narration, even though - unlike Lord of the Flies - it is more clearly focalised through a single character, Maitland. One reason the story cannot be conveyed to the reader solely through Maitland's consciousness is the fact that in its course he gets up to some morally indefensible things. Rather than seeing them in the cold light of day, the reader would perceive these through a filter of justifications and rationalisations if Concrete Island was a first-person account. The second reason why Ballard's novel avoids first-person narration is that Robert Maitland himself is not always fully aware of why he acts the way he acts, thus again making it impossible for him to tell his story honestly without resorting to more rationalisations. The text does give us brief glimpses of insight into his psyche, such as the contention that "he himself had almost deliberately created this situation [on the island]" (26), but they are given without any comment whether Maitland himself fully grasps these ideas. The third reason a third-person narrative is more functional here is the simple fact that Maitland is not in control of the narrative nor in any position to decisively shape it. Without agency over their own story, first-person narrators in Robinsonades make very little sense, and in the case of Maitland, it soon becomes clear that whatever he or the reader may have perceived as a struggle initially is actually no contest at all. In the end, if anyone can be said to be in control, it is the concrete island itself, not any of its human denizens. And the final reason a first-person narration would not work here is that once 
Maitland has succumbed to the will and the brutalising logic of the island itself, there can be no triumphant survivor retrospectively imbuing the story with meaning. That is the strangely dystopian direction the Robinsonade can take when neither the crafting of a cohesive narrative nor the triumph of the individual over their surroundings is the stated desideratum:

[T] he Ballard hero typically prefers the disaster or the cataclysm to the former state of plenty. [...] This quiescent and anti-triumphant form is continued in Ballard's contemporary social fiction in which the hero discovers himself in a disastrous heterocosm that he prefers to the outside world (most especially in Concrete Island and High Rise). Even when these characters are offered the chance of rescue or escape from the disaster, they doggedly hold to chaos and sometimes certain death. (Orr 479)

The fact that Robert Maitland is an architect and as such partly responsible for the built environment to whose will he must finally submit is of course the supreme irony of Ballard's Concrete Island. Rather than stating that civilisation is under constant attack from our own worst impulses, as could be said of Lord of the Flies, Ballard's novel argues that civilisation itself has gone too far, turning our surroundings into dehumanising concrete deserts. While their attitudes to civilisation may differ considerably, however, both Golding and Ballard employ the form of the Robinsonade to make their points, subverting the genre to turn it into a dystopian form "designed to arouse moral anxiety and inhibit triumphal action" (Green 3). In creating these dystopias, both writers are heavily reliant on ideas of setting and context, the one choosing a nuclear war, the other a 1970 concrete wasteland. What their dystopias rely on in equal measure is the omission of one of the Robinsonade's most prominent traits - its foregrounding of the narrative process.

\section{The Red Turtle and the Sustainable Absence of Civilisation}

The final work to be discussed here deviates from those outlined above in that its omission of discourse is by no means intended to evoke the same dystopian atmosphere caused by misguided attempts at establishing human dominion over a geographical feature. Instead, Michael Dudok de Wit's The Red Turtle (2016) ${ }^{2}$

2 The DVD referenced in the References is the American version, which appeared in 2017. As both the French and Japanese DVDs were available earlier and the film had its theatrical release in $\mathbf{2 0 1 6}$, that is the year of publication given in the text. 
is an animated film that tries to eschew anthropocentric perspectives as far as possible, leaving very little room for the fashioning of narratives along the way. When its nameless protagonist is washed ashore at the very beginning, he enters a world not yet subjugated by man. Uncharacteristically for a Robinsonade, that is a state that will largely be maintained throughout the film. There is none of the expansionist agenda so prominent in Defoe's original text:

Crusoe asserts his authority -- his ordering capacity -- over more and more important and wider and wider areas. He arranges his possessions on shelves within his house; he plants fields; he pens in animals; and finally he presides ... as "my majesty, the prince, and lord" over his "little Family" of animals. (Birdsall 30)

Instead, what we see in Dudok de Wit's film is an unusual neglect of human dimensions. No background story is given as to the causes, consequences or morality of the shipwreck. The castaway is simply there amidst the waves, struggling for survival. Rather than opening with a shot of the castaway's face, the next scene opens with some crabs scuttling along the beach and past the prone body of the castaway - a frequent technique repeated with various animals from sea lions to birds: the scene never opens with the human, it opens with some animals going about their daily chores that happen to pass a human on whose form our gaze can then fall as if by accident. The only times the concept of culture in the form of manmade structures and rituals comes up is really in the castaway's dreams: when he imagines a bridge built of bamboo or sees himself dancing to an imaginary string quartet. Given its limited cast, it could be assumed that emotional identification with its central character must be the film's primary concern, but the man's Tintin-like features do not lend themselves to particularly powerful facial expressions, and, as one critic notes, " $\mathrm{t}]$ here aren't too many facial close-ups - about as many as there are of spiders and caterpillars, crabs and leaves" (Stevens 35). In its framing of its central character in his island surroundings, the film goes out of its way to avoid the anthropocentrism that is the default setting of all storytelling. Days and events come and go, no unnecessary burden of causality or morality is placed on the various goings-on, and our protagonist is just another organism in the ecosystem of the island. In fact, he integrates impeccably, for instance by using predominantly fallen bamboo trees in his efforts to build a raft. Instead of being shown to take possession of the island by subjugating it to his will, the protagonist is rather shown exploring it, learning to live with its geography on its terms rather than his. And just as he does not take possession of the island 
physically, he does not exert any narrative power over it either. This may be the case because he is at first the only human on the island, but even when he acquires some companions, the shaping of the narrative so typical of the Robinsonade is unequivocally omitted. After all, and most importantly, the film is "completely wordless" (Stevens 35 ). ${ }^{3}$ Given its non-verbal nature, it stands to reason that the film avoids the establishment of narrative discourse to an extent a novel could simply never do. In the novels discussed above, that type of attempted omission invariably leads to a dystopian state questioning humanity's ability to exert rational power over nature in the case of Lord of the Flies or the built environment in Concrete Island. The Red Turtle instead gives us a utopian vision of total immersion reminiscent of " $\mathrm{t}]$ he motif from Romantic painting of an individual subsumed by nature" (Stevens 35 ). No longer identified with ideas of civilisation, cultivation and domination, humanity in Dudok de Wit's film can forgo attempts at physical and verbal empire building and instead be at one with nature.

When Ann Marie Fallon argues that the Robinsonade has come "to represent the transnational anxieties around literary influence, value, and linguistic power in the second half of the twentieth century" (2011), the specimens under discussion in the present essay have by their very nature focused on the question of linguistic power, often in the form of narrative agency. While most Robinsonades, particularly since the middle of the twentieth century, have adopted the narrative situation of Defoe's original novel in order to demonstrate the nature of these struggles for various forms of dominance, there have also been modern Robinsonades deliberately eschewing participation in metafictional discourse of that type. And while these Robinsonades are all characterised by the omission of discourse, by their refusal to thematise the genesis of their text as text, they do so to very different ends. In Golding's and Ballard's twentieth-century dystopias, the absence of linguistic power reflects a lack of agency on the part of the protagonists: having been abandoned by civilisation, the boys in Lord of the Flies attempt to recreate it but ultimately fail and are overpowered by their baser instincts. Having spent his architectural career contributing to the development of the concrete jungle, Robert Maitland, the protagonist of Concrete Island, is ultimately defeated by the brutalising urban space he finds himself

3 This is to some extent a matter of definition as there are a number of occasions on which the protagonist shouts a single "Hey!", a word that is used here variously to express anger, desperation, or exasperation. The fact that these occasions can be counted on the fingers of a single hand, however, means that even if you consider "hey" a word, the film can still be considered as operating virtually without any language. 
in. To him, civilisation is not what offers salvation - it is what causes our own inhumanity. In contrast to these dystopias concerned with the "nightmarish moral possibilities of the castaway life" (Green 181), Dudok de Wit's The Red Turtle provides an ecological utopia suggesting that the powerlessness embodied on multiple levels of the film may not be a defeat but an acceptance that exercising the type of civilisatory power often seen at work in the Robinsonade may not offer a sustainable mode of existence.

\section{| References}

Ballard, J.G. 1974. Concrete Island. London: Fourth Estate, 2014.

Barrie, J.M. Peter Pan and Other Plays. Ed. Peter Hollindale. Oxford: Oxford University Press, 1995.

Birdsall, Virginia Ogden. Defoe's Perpetual Seekers: A Study of the Major Fiction. Lewisburg: Bucknell University Press, 1985.

Defoe, Daniel. 1719. Robinson Crusoe: An Authoritative Text, Contexts, Criticism.

Ed. Michael Shinagel. New York: Norton, 1994.

Fallon, Ann Marie. Global Crusoe: Comparative Literature, Postcolonial Theory and Transnational Aesthetics. Farnham: Ashgate, 2011.

Golding, William. 1954. Lord of the Flies. London: Penguin, 1960.

Green, Martin. The Robinson Crusoe Story. University Park: Pennsylvania State University Press, 1990.

Kinane, Ian. Theorising Literary Islands: The Island Trope in Contemporary Robinsonade Narratives. London: Rowman and Littlefield, 2017.

Mitchell, Adrian. Man Friday and Mind Your Head. London: Eyre Methuen, 1974. Orr, Leonard. “The Utopian Disasters of J.G. Ballard”. CLA Journal 43(4) (2000). 479-493.

The Red Turtle. Dir. Michael Dudok de Wit. Culver City: Sony Pictures Home Entertainment, 2017.

Richetti, John. "Defoe as Narrative Innovator." The Cambridge Companion to Daniel Defoe. Ed. John Richetti. Cambrige: Cambridge UP, 2008. 121-138. Stevens, Isabel. "Cast Away." Sight \& Sound. July 2016. 35. 


\section{| Abstract}

PATrick Gill

Dystopian and Utopian Omission of Discourse in Three Modern Robinsonades: Lord of the Flies, Concrete Island, The Red Turtle

The story of Robinson Crusoe comes to us in the guise of a first-person narrative based in part on a diary. Successor texts have traditionally adopted the same narrative situation, exploiting it in order to foreground ideas of authorship, textual authority and linguistic dominance. This essay pays particularly close attention to those Robinsonades that have not followed this pattern and have instead opted to omit meta-narration and intradiegetic narrator figures. It considers to what ends this is done in three modern Robinsonades: William Golding's Lord of the Flies (1954), J.G. Ballard's Concrete Island (1974), and Michael Dudok de Wit's animated film The Red Turtle (2016).

Keywords: Robinsonade, Defoe, metafiction, discourse, narrator, dystopia

\section{| Abstrakt}

\section{Patrick Gill}

Dystopijne i utopijne pominięcie dyskursu w trzech nowoczesnych robinsonadach: Władcy much, Wyspie i Czerwonym żótwiu

Historia Robinsona Crusoe przedstawiona jest za pomocą narracji w pierwszej osobie częściowo napisanej w formie dziennika. Teksty kontynuujące tradycję robinsonady na ogół również przyjmowały podobną narrację, uwypuklając w ten sposób kwestię autorstwa, władzy nad tekstem i dominacji językowej. Niniejszy artykuł skupia się na tych robinsonadach, w których nie zastosowano wyżej opisanej techniki, co pozwoliło wyeliminować metanarrację i intradiegetycznego narratora. Celem jest ustalenie powodu takiego zabiegu na przykładzie trzech nowoczesnych robinsonad: Władcy much Williama Goldinga (1954), Wyspy J.G. Ballarda (1974) i filmu animowanego Michaela Dudok de Wita pod tytułem Czerwony żółw (2016).

Słowa kluczowe: robinsonada, Defoe, metafikcja, dyskurs, narrator, dystopia 
| Bio

Patrick Gill is a senior lecturer at Johannes Gutenberg University in Mainz where he also received his Ph.D. He is the author of Origins and Effects of Poetic Ambiguity in Dylan Thomas's Collected Poems (2014) and the co-editor of Constructing Coherence in the British Short Story Cycle (2018). He has lectured and published on English poetry, the contemporary novel, and British and American media culture. His ongoing research is into the efficacy of literary form.

E-mail: patrick.gill@uni-mainz.de 